\title{
Katarzyna Balbuza
}

Uniwersytet im. Adama Mickiewicza w Poznaniu balbuza@amu.edu.pl

\section{IDEA AETERNITAS AUGUSTI - POCZATTKI I KIERUNEK ROZWOJU*}

Kiedy w początkach pryncypatu idea aeternitas ${ }^{1}$ zaczynała swoją powolną i dość opieszałą ",karierę” w ramach ideologii władzy cesarskiej, jej historia sięgała schyłku republiki, lat 80. I wieku p.n.e., choć sama koncepcja nieograniczonego trwania, rozumiana w kontekście czasu istnienia państwa, była rozważana wcześniej². Celem niniejszych rozważań jest ukazanie wcze-

* W niniejszym szkicu przedstawiam skrót głównych tez na temat genezy tytułowej idei (w uaktualnionej formie), które znalazły się w mojej książce pt. Aeternitas Augusti. Kształtowanie się i rozwój koncepcji wieczności w (auto)prezentacji cesarza rzymskiego (od Augusta do Sewera Aleksandra), opublikowanej w Wydawnictwie Poznańskim w 2014 r.

${ }^{1} \mathrm{O}$ etymologii aeternitas zob. K. Balbuza, op. cit., s. 30-37. Por. również G. Furlanetto, Lexicon totius Latinitatis opera et studio Aegidii Forcellini lucubratum et in hac edition post tertiam auctam et emendatam a Josepho Furlanetto, Prati 1858-1887, s. 150-151; A Latin Dictionary. Founded on Andrews' Edition of Freund's Latin Dictionary, ed. by Ch. T. Lewis, Ch. Short, Oxford 1879: zob. hasło aeternitas, -atis; ibidem: zob. hasło aevum, $-i$ : „uninterrupted, never-ending time, eternity"; Lateinisches etymologisches Wörterbuch, hrsg. von A. Walde, J.B. Hoffmann, Bd. 1, Heidelberg 1930, s. 21; Dictionnaire etymologique de la langue latine. Histoire de mots, vol. 1, éd. par A. Ernout, A. Meillet, Paris 1959, s. 13-14; Indogermanisches etymologisches Wörterbuch, hrsg. von J. Pokorny, Bern 1959, s. 17-18; S. Luciani, D'aićv à aeternitas: le transfert de la notion d'éternité chez Cicéron, "Ars Scribendi” 2006, nr 4, s. 8-9; Etymological Dictionary of Latin and Other Italic Languages, ed. by M. De Vaan, Leiden 2008, s. 29; H.M. Keizer, LIFE - TIME ENTIRETY. A Study of AIQN in Greek Literature and Philosophy, Amsterdam 2010, s. 250.

2 Por. np. M.D. Dopico Caínzos, Le concept de l'«aeternitas» de Rome: sa diffusion dans la société romaine, „Les Études Classiques” 1998, nr 66(3), s. 259-279; eadem, La economía política de los Romanos: Aeternitas rerum. La aspiración a la estabilidad de un sistema histórico, Santiago de Compostela 2011, s. 19-30. 
snocesarskich korzeni idei aeternitas odnoszonej do osoby cesarza. Zanim bowiem stała się ona jego oficjalnym atrybutem (aeternitas Augusti), wyróżnikiem boskiej natury cesarza, definiującym jego status i potencjał, najwyższym stopniem szczęścia, zawierającym życzenie niekończącej się sławy i zaszczytów ${ }^{3}$, jedną z deifikowanych abstrakcji (abstracta), wyrażającą stan pożądany (res expetendae), który cesarz mógł osiągnąć w wyniku ubóstwienia - wzmiankowano o niej w sposób nieoficjalny w poezji, w mennictwie prowincjonalnym oraz $\mathrm{w}$ napisach epigraficznych.

Forma rzeczownikowa aeternitas, oznaczająca wieczność/wiecznotrwałość ${ }^{4}$, pojawia się w literaturze łacińskiej najwcześniej u Marka Tulliusza Cycerona (M. Tullius Cicero), pierwszego autora łacińskiego, a zarazem jedynego $\mathrm{w}$ tamtej epoce, który $\mathrm{w}$ swoich pismach stosował wspomniany termin ${ }^{5}$. W początkach pryncypatu idea aeternitas występuje $\mathrm{w}$ odniesieniu między innymi do osoby princepsa, zyskując indywidualne zabarwienie. Pierwsze poświadczenia występowania idei aeternitas odnajdujemy w dziełach poetyckich z czasów Augusta, gdzie jest mowa o aeternitas Westy ${ }^{6}$, ognia płonącego $\mathrm{w}$ jej świątyni ${ }^{7}$, Apollona czy samego princepsa ${ }^{8}$. W kontekście tego ostatniego szczególnie istotny jest przekaz Owidiusza, który aeternitas Westy łączy z aeternitas pierwszego princepsa. W dziele pod tytu-

${ }^{3}$ P. Strack, Untersuchungen zur römischen Reichsprägung des zweiten Jahrhunderts. Die Reichsprägung zur Zeit des Hadrian, Bd. 2, Stuttgart 1933, s. 65.

${ }_{4} \mathrm{Na}$ temat granic czasowych aeternitas zob. ostatnio M.D. Dopico Caínzos, La economía, s. $76-82$.

5 Oratoria: Cic. Pis. 7; Cic. Marcell. 28; Cic. Phil. 14.34. Philosophia: Cic. Inv. rhet. 1.39; Cic. De or. 3.20; Cic. Top. 59; Cic. Fin. 2.88; 89; Cic. Tusc. 1.38; 50; 55; 80; 81; 94; 4.37; 5.70; Cic. Nat. D. $1.21 ; 114 ; 2.43 ; 51 ; 54 ; 62 ; 95 ; 3.14$; Cic. Div. $1.25 ; 115 ; 125 ; 2.19$; Cic. Fat. $19 ; 21 ; 27 ; 29 ; 32 ; 33$; 37; 38. Po raz pierwszy termin aeternitas pojawia się we wczesnym, młodzieńczym dziele $D e$ inventione, podręczniku retoryki, powstałym w latach około 84-83 p.n.e. (Cic. Inv. rhet. 1.39). O aeternitas w dziełach i myśli Cycerona zob. J. Vogt, Ciceros Glaube an Rom, Darmstadt 1963, s. 72-101; M.D. Dopico Caínzos, Una aproximacion al significado de aeternitas en Ciceron, "Res Publica Litterarum. Studies in the Classical Tradition" 1996, nr 19, s. 45-58; eadem, Aeternitas rei publicae como programa politico en Ciceron: el ejemplo del Pro Marcello, "Athenaeum" 1997, nr 85(2), s. 391-408; eadem, Le concept, op. cit., s. 265; eadem, La economia, op. cit., s. 30-36; K. Balbuza, Aeternitas Augusti, op. cit., s. 41-47.

6 Westę, boginię wiecznego ogniska, epitetem aeterna obdarza Horacy w Carmina przy okazji wyliczania pignora imperii stanowiących rękojmię wiecznotrwałości Rzymu (Hor. Carm. 3.5.9-12)

7 Ogień Westy jako aeternus: Cic. Font. 27; Verg. Aen. 2.154; 2.296-297; 4.198-202; Ov. Fast. 3.421. Por. też Ov. Fast. 6.297; Liv. 5.52.7; 26.27.14; Val. Max. 1.1.6; por. też Val. Max. 4.4.11 i 5.4.7; Vell. Pat. 2.131.

$8 \mathrm{O}$ aeternitas $\mathrm{w}$ poezji augustowskiej zob. ostatnio K. Balbuza, The Idea of Aeternitas of the State, City and Emperor in Augustan Poetry, "Klio" 2014, nr 96(1), s. 49-66; eadem, Aeternitas Augusti, op. cit., s. 48-58 i 133-134. Por. też: S. Śnieżewski, Problem boskości Oktawiana - Augusta w poezji augustowskiej, Kraków 1993, s. 71-72. 
łem Fasti zwraca on uwagę na religijny kontekst aeternitas Augusta, która zasadzała się zarówno na przekonaniu o jego boskiej naturze, jak i na stwierdzeniu sakralnego, nierozerwalnego związku z boginią Westą9. Okazją do wspomnianych wypowiedzi poetyckich Owidiusza były wydarzenia z 12 roku p.n.e. (6 marca $\left.{ }^{10}\right)$, kiedy August objął funkcję najwyższego pontyfika (Pontifex Maximus) ${ }^{11}$ oraz roztoczył opiekę nad kultem Westy, którą powiązano $\mathrm{z}$ domem Augusta na Palatynie poprzez ustanowienie ołtarza jej poświęconego ${ }^{12}$. Domus Augusta stała się w ten sposób miejscem szczególnym, „zamieszkałym” przez Westę, Apollona (Apollo Phoebus) i samego Augusta, zaliczanych przez poetę do tworu na kształt "trójcy boskiej"13. Ważne jest tu stwierdzenie wieczności bóstwa (nominis) Augusta i wieczności ognia Westy, a następnie jedności między nimi. Poeta uwypukla tę sakralną relację, w której Westa czuwa nad życiem cesarza, on sam natomiast dba o jej ogień. Ponadto, co interesujące, Westa jest określona jako cognata względem cesarza ${ }^{14}$. W powstałym na wygnaniu zbiorze elegii Ex Ponto Owidiusz wprost określa Augusta mianem wiecznego (princeps aeternus) ${ }^{15}$.

Powyższe przykłady dowodzą, że odnoszona do osoby princepsa idea aeternitas funkcjonowała zrazu $\mathrm{w}$ literaturze rzymskiej $\mathrm{w}$ odniesieniu do cesarza żyjącego. W tym kontekście szczególne znaczenie mają pochodzące z rzymskiej Hiszpanii monety - pierwsze dowody użycia terminu aeternitas w mennictwie antycznym - które dowodzą, że ideę aeternitas stosowano

${ }^{9}$ Ov. Fast. 3.421-428; 4.949-954. Zob. też: Ov. Met. 15.864-865. Por. S. Śnieżewski, op. cit.

10 A. Degrassi, Inscriptiones Italiae, vol. XIII.2: Fasti Numani et Iuliani, Roma 1963, s. 121 (,Fasti praenestini”).

${ }_{11}$ Ov. Fast. 3.3.415-428; RG 10; Suet. Aug. 31; App. B Civ. 5.13.131; Cass. Dio 54.27.2 (podaje błędną datę: 13 r. p.n.e.). Szerzej: G. Herbert-Brown, Ovid and the Fasti. An Historical Study, Oxford 1994, s. 63-81; L. Schumacher, AVGVSTVS PONT. MAX. - Wie wurde ein römischer Kaiser Pontifex Maximus?, „Klio" 2006, nr 88, s. 181-188.

12 Szerzej na temat kultu Westy na Palatynie wraz z odwołaniami do literatury przedmiotu zob. K. Balbuza, Aeternitas Augusti, op. cit., s. 52-54, przyp. 218.

13 Ov. Fast 4.954. O boskości Augusta poeta wspomina też w innych miejscach swojego dzieła: Ov. Fast. 1.530 (prawdopodobnie chodzi o Augusta, lecz nie wyklucza się też Juliusza Cezara; por. komentarze: J.G. Frazera: Publii Ovidii Nasonis Fastorum libri sex. The Fasti of Ovid, ed. by J.G. Frazer, Vol. 2, London 1929, s. 205; oraz S.J. Greena: Ovid, Fasti 1. A Commentary, ed. by S.J. Green, Leiden \& Boston 2004, s. 243); Ov. Fast. 3.421-422. Na temat boskości Oktawiana/Augusta w twórczości poetów z okresu augustowskiego zob. szczególnie: S. Śnieżewski, op. cit., passim.

${ }^{14}$ Interesującą propozycję wyjaśnienia wspomnianego związku sakralnego Augusta i Westy przedstawił onegdaj J.G. Frazer w komentarzu do trzeciej księgi Fasti Owidiusza, który zwrócił uwagę na "genealogię" Augusta: „,...] Augustus was only an adoptive son of Julius Caesar, who was descended from Aeneas, who was a son of Venus, who was a daughter of Jupiter, who was a son of Saturn, who was own brother of Vesta"; Publii Ovidii Nasonis, s. 97.

${ }^{15}$ Ov. Pont. 2.2.47-48. 
również wobec cesarza konsekrowanego, przynajmniej od drugiego dziesięciolecia I wieku n.e. Monety zostały bowiem wyemitowane za Tyberiusza ku czci zmarłego, a następnie ubóstwionego Augusta. Za pomocą oryginalnej i również w późniejszym czasie niewystępującej nigdzie formuły aeternitas Augusta głosiły wieczność boskiego pierwszego princepsa16 (il. 1).
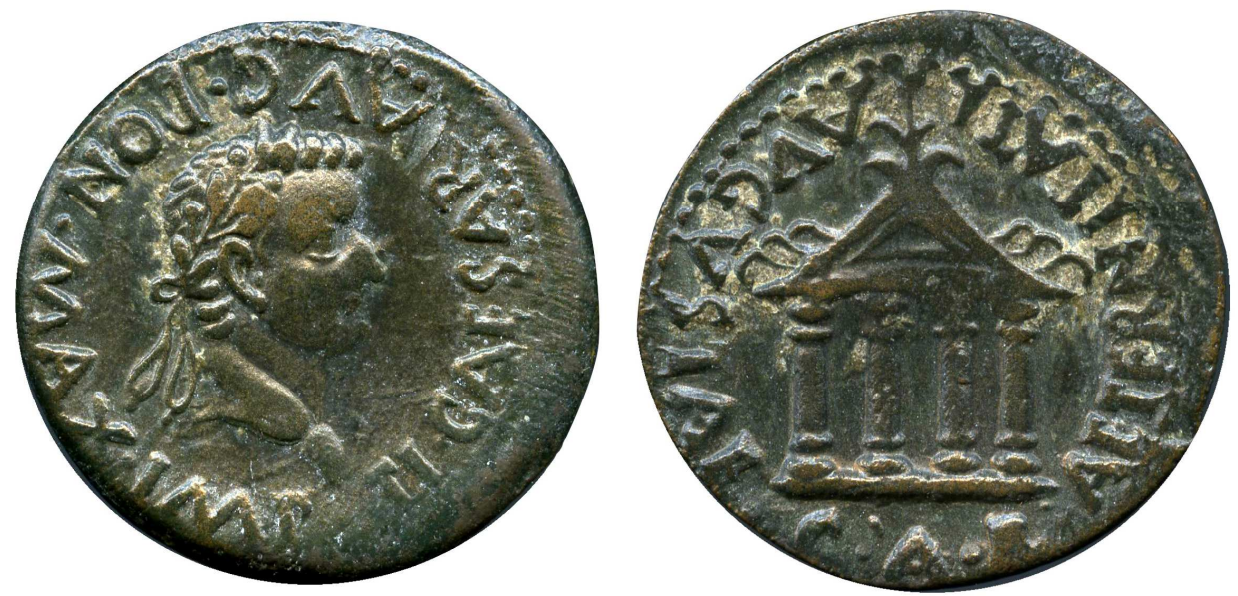

Il. 1. As (Augusta Emerita, Hiszpania), po 15 r. n.e. Awers: TI CAESAR AVG PON MAX IMP. Głowa Tyberiusza w wieńcu laurowym. Rewers: AETERNITATI AVGVSTAE C A E. Świątynia typu tetrastylos, RPC 1, 48. (C) Trustees of the British Museum

Mimo że w tym okresie są to odosobnione świadectwa traktowania cesarza zmarłego i konsekrowanego jako wiecznego, przyjął się zwyczaj mówienia $\mathrm{w}$ ten sposób o ubóstwionym cesarzu, co potwierdzają dane numizmatyczne z okresu późniejszego. Między aeternitas cesarzy żyjących i zmarłych nie było jednak wielkiej różnicy ${ }^{17}$. Tak zwana ziemska aeternitas przeobrażała się $\mathrm{w}$ pewnym momencie, to jest po śmierci, $\mathrm{w}$ tak zwaną niebiańską

16 Tarraco: RPC 1.219; 222; 224; 226. Emerita: RPC 1.29; RPC 1, Suppl. 2.29; RPC 1.47-48; RPC 1, Suppl. 2.47. O mennictwie konsekracyjnym Augusta z czasów Tyberiusza zob. K. Balbuza, Koncepcja wieczności państwa w Rzymie Augusta, w: Haec mihi in animis vestris templa. Liber in memoriam Leslai Morawiecki, red. P. Berdowski, B. Blahaczek, Rzeszów 2007, s. 201-202; eadem, Aeternitas cesarzy w mennictwie konsekracyjnym Imperium Romanum w okresie od Augusta do Antoninów, w: Świat starożytny, jego polscy badacze i kult panujacego, red. L. Mrozewicz, K. Balbuza, Poznań 2011, s. 297-312; eadem, La conception d'Aeternitas dans le monnayage de consecration romain de l'epoque du principat, „Palamedes” 2011, nr 6, s. 93-99; eadem, Aeternitas Augusti, passim, zwłaszcza s. 58-64.

${ }_{17}$ F. Sauter, Der römische Kaiserkult bei Martial und Statius, Stuttgart-Berlin 1934, s. 131. Por. też: L. Berlinger, op. cit., s. 41. 
aeternitas ${ }^{18}$. Wiązał się z tym rytuał ubóstwienia i zjawisko kultu panującego, które narodziło się w tym samym czasie co koncepcja wiecznotrwałości cesarza konsekrowanego ${ }^{19}$. Konsekracja już dokonana lub nadzieja na ów prawnie usankcjonowany stan ubóstwienia była pierwszym sensem wieczności cesarza (aeternitas Augusti).

Idea aeternitas cesarza żyjącego i konsekrowanego rodziła się w relacji z funkcjonującą jednocześnie ideą wieczności państwa/władzy (aeternitas Imperii ${ }^{20}$. Druga $\mathrm{z}$ wymienionych koncepcji stoi u podstaw ideologii aeternitas, z której wyrośnie i w której będzie się zawierała koncepcja aeternitas Augusti $^{21}$. Dla Rzymian wieczny (aeternus) był przede wszystkim sam Rzym

18 R. Reitzenstein, Das iranische Erlösungsmysterium, Bonn 1921, s. 224; F. Sauter, op. cit., s. 131.

${ }^{19}$ Na temat pojęcia i zjawiska tak zwanego „kultu panującego” toczą się dyskusje i istnieje ogromna literatura przedmiotu. Odesłanie do dyskusji i do literatury zob. ostatnio: K. Balbuza, Aeternitas Augusti, op. cit., s. 14, przyp. 20.

20 O wiecznotrwałości miasta Rzym i państwa za Augusta por. Tib. 2.5.23; Liv. 4.4; 28.28.11. Zob. przede wszystkim: C. Koch, Roma Aeterna. Studien zu Kult und Glauben der Römer, "Gymnasium" 1952, nr 59, s. 128-143 i 196-209 (=Roma Aeterna, w: Religio. Studien zu Kult und Glauben der Römer, hrsg. von Otto Seel, Nürnberg 1960, s. 142-175); ostatnio m.in. K. Balbuza, Koncepcja wieczności..., op. cit., s. 197-204; eadem, Aion z Afrodyzjas i koncepcja filozoficzna saeculum aureum Augusta, w: Społeczeństwo i religia w świecie antycznym. Materiały z ogólnopolskiej konferencji naukowej (Toruń, 20-22 września 2001 r.), red. S. Olszaniec, P. Wojciechowski, Toruń 2010, s. 207-226. Na temat aeternitas Imperii zob. przede wszystkim: R. Turcan, Rome éternelle et les conceptions gréco-romaines de l'Eternité, w: Roma Costantinopoli, Mosca. Atti del I Seminario Internazionale di Studi storici, Napoli 1983, s. 7-30; R. Étienne, Aeternitas Augusti-Aeternitas Imperii. Quelques apercus, w: Les grandes figures religieuses fonctionnement pratique et symbolique dans l'Antiquite. Besançon 25-26 avril 1984, Paris 1986, s. 445-454; M.D. Dopico Caínzos, Aeternitas civitatis como programa histórico, „Rivista storica dell'antichità” 1990, nr 20, s. 49-67; eadem, Sobre los orígenes del concepto aeternitas civitatis, w: Homenaje al professor Presedo, coord. S.M. Ordóñez Agulla, P. Sáez Fernández, Sevilla 1994, s. 811-824; eadem, Le concept..., op. cit., s. 259-279; eadem, "Aeternitas" o desaparición de Roma?: dos visiones de la sociedad romana, "Quaderni urbinati di cultura classica" 1999, nr 63, s. 139-161; eadem, La economía, op. cit.; N. Méthy, Rome, „ville éternelle"? À propos de deux vers de Tibulle (II, 5, 23-24), „Latomus” 2000, nr 59, s. 68-81 (w kontekście poezji Tibullusa); S. Benoist, Rome, le prince et la Cité. Pouvoir impérial et cérémonies publiques (Irer siècle av.-début du IVe siècle apr. J.-C.), Paris 2005, s. 309-326; A. Lichtenberger, Severus Pius Augustus. Studien zur sakralen Repräsentation und Rezeption der Herrschaft des Septimius Severus und seiner Familie (193-211 n. Chr.), Leiden - Boston 2011, s. 219-279 (w odniesieniu do dynastii Sewerów); K. Balbuza, Aeternitas Augusti, op. cit., passim (z odesłaniem do literatury przedmiotu na s. 33, przyp. 116). W okresie późnoantycznym: F. Paschoud, Roma Aeterna. Études sur le patriotisme Romain dans l'Occident Latin a l'époque des grandes invasions, Neuchâtel 1967; D. Brodka, Die Idee der "Roma Aeterna" in den Kaiserpanegyriken des Sidonius Apollinaris, w: Studies of Greek and Roman Antiquity, ed. by J. Styka, Kraków 1997, s. 121-128; idem, Idea Rzymu w literaturze rzymskiej późnego antyku, „Nowy Filomata” 1998, nr 2, s. 83-97; idem, Die Romideologie in der römischen Literatur der Spätantike, Frankfurt am Main 1998.

${ }^{21}$ R. Reitzenstein, op. cit., s. 222: „der Begriff [tj. aeternitas Imperii - przyp. K.B.] älter ist [niż aeternitas Augusti - przyp. K.B.]. Er ist nicht vom Kaiserkult auf das Reich, sondern vom Reichsgedanken auf den Kaiser übertragen". Wcześniej taką samą opinię wyrażali P. Strack: 
i jego mieszkańcy, dopiero później władza cesarza czy sam cesarz. Dlatego kształtowanie się koncepcji wieczności cesarza to proces powolnego, lecz konsekwentnego przenoszenia postulatu wieczności z miasta na osobę. Pierwszym autorem starożytnym, który w swojej elegii wymienił frazę aeterna Urbs, był tworzący za Augusta Albius Tibullus22. Również Liwiusz przypominał w swoim monumentalnym dziele o tym, że Rzym został założony na wieczność („Urbs in aeternum condita”) ${ }^{23}$. Istotne znaczenie miał w tych przekazach sam akt fundacyjny Rzymu, który oznaczał dla poetów i historiografów augustowskich ten punkt czasowy, do którego odnosiła się aeternitas miasta i państwa. Równie ważny był tu jednak legendarny bohater odpowiedzialny za założenie miasta - Romulus to, według Owidiusza, ojciec wiecznego Miasta („,aeternae pater urbis”) ${ }^{24}$. W podobnym duchu wspomniał go Waleriusz Maksymus ${ }^{25}$. W chwili narodzin pryncypatu osoba princepsa stała się tą, z którą wiązano nadzieje na bezpieczeństwo i wiecznotrwałość państwa. Ideę wieczności państwa w tym kontekście uwypuklono wpierw w nawiązaniu do adopcji (adoptio) politycznej Tyberiusza przez Augusta (4 r. n.e.). Akt ten, otwierający pasierbowi pierwszego princepsa drogę do sukcesji, wzbudził w społeczeństwie, zdaniem Wellejusza Paterkulusa, radość (laetitia) oraz ufność w nieustające bezpieczeństwo i wieczność imperium rzymskiego (,perpetuae securitatis aeternitatisque Romani imperii" $)^{26}$. W ten sposób historyk wyeksponował jeden $\mathrm{z}$ istotniejszych sensów idei aeternitas w kontekście cesarza żyjącego - sukcesję jako warunek trwałości i bezpieczeństwa państwa ${ }^{27}$. Udobitnienie roli cesarza/sukcesora warunkującego aeternitas państwa, ukazanie go jako gwaranta tejże aeternitas, nie było przypadkiem odosobnionym $\mathrm{w}$ tym czasie. Inskrypcja $\mathrm{z}$ Interamna

Untersuchungen zur römischen Reichsprägung des zweiten Jahrhunderts. Die Reichsprägung zur Zeit des Traian, Bd. 1, Stuttgart 1931, s. 187; oraz L. Berlinger: Beiträge zur inoffiziellen Titulatur der römischen Kaiser. Eine Untersuchung ihres ideengeschichtlichen Gehalten und ihrer Entwicklung, Breslau 1935, s. 30; zob. ibidem, s. 41: „In der Aeternitas Imperii ist die Aeternitas Augusti eingeschlossen".

22 Tib. Eleg. 2.5.23.

${ }^{23}$ Liv. 4.4: "Quis dubitat quin in aeternum urbe condita, in immensum crescente nova imperia, sacerdotia, iura gentium hominumque instituantur?”; Liv. 28.28.11: „ne istuc Iuppiter optimus maximus sirit, urbem auspicato dis auctoribus in aeternum conditam huic fragili et mortali corpori_aequalem esse.” Por. Tac. Ann. 3.6: „principes mortalis, rem publicam aeternam esse".

24 Ov. Fast. 3.71-72.

25 Val. Max. 5.3.1.

26 Vell. Pat. 2.103.3-5.

${ }^{27}$ Szerzej na ten temat zob. K. Balbuza, Aeternitas Augusti, op. cit., s. 137-178. O politycznej sukcesji za rządów cesarzy z dynastii julijsko-klaudyjskiej zob. P. Sawiński, Sukcesja władzy cesarskiej w okresie rząów dynastii julijsko-klaudyjskiej (30 p.n.e.-68 n.e.), Poznań 2016. 
Nahars, pochodząca przypuszczalnie z ołtarza publicznego, erygowanego w 32 roku n.e. i dedykowanego między innymi zdrowiu cesarza (salus), wolności ludu rzymskiego (libertas) i opatrzności (providentia) cesarza Tyberiusza - jest tego dobrym przykładem (il. 2) ${ }^{28}$.

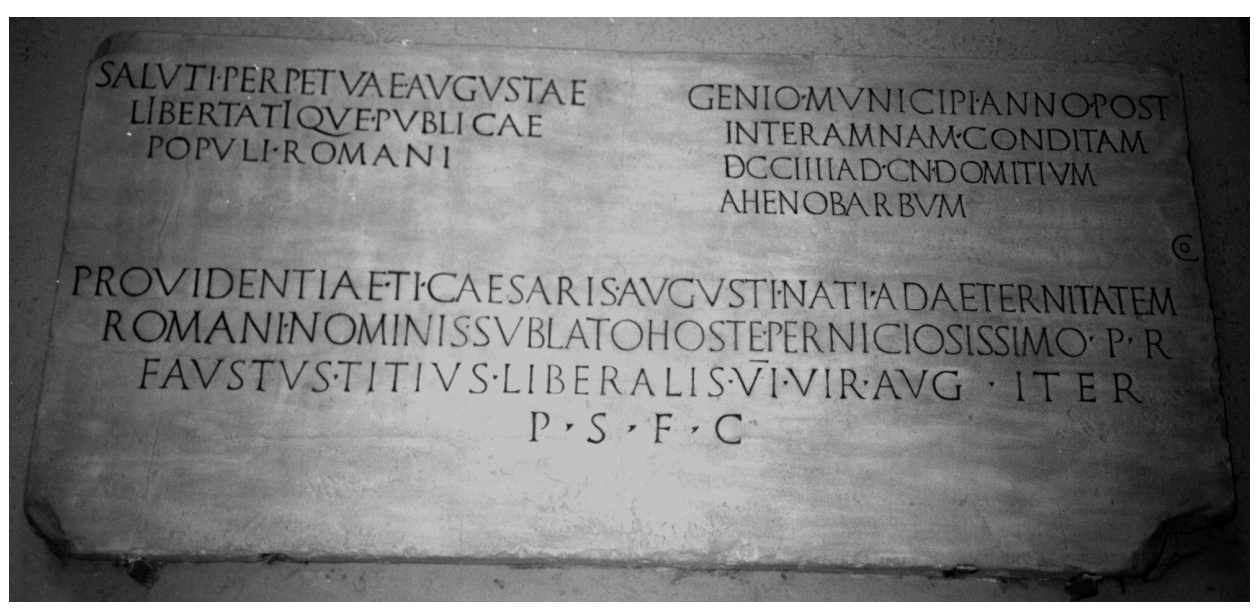

Il. 2. CIL 11.4170 (Interamna Nahars, Umbria, Włochy). @ G. Alföldy. EDH F009251

Wystawca zadedykował ołtarz Tyberiuszowi, który - jak czytamy - urodził się dla zapewnienia wiecznotrwałości nominis Rzymu („,natus ad aeternitatem Romani nominis"). Co interesujące, za tą inicjatywą stał niejaki Faustus Tycjusz Liberalis, miejscowy sevir augustalis, a więc członek ustanowionego przez Tyberiusza kolegium sześciu kapłanów odpowiedzialnych za kult ubóstwionych - Augusta i innych członków rodu julijskiego. Ma to istotne znaczenie dla idei aeternitas rozumianej zarówno w kontekście władcy zmarłego, jak i żyjącego. Doskonałym przykładem traktowania cesarza - jak również potencjalnych następców "tronu" - jako poręczycieli wieczności państwa jest inne świadectwo epigraficzne, pochodzące również z czasów Tyberiusza (z okresu ok. 23-37 r. po Chr. ${ }^{29}$ ), stanowiące element akweduktu (aqua Augusta) wzniesionego w Peltuinum (il. 3). Napis został dedykowany wieczności cesarzy (,pro aeternitate caesarum”) 30 - Tyberiusza i (przypuszczalnie) jego wnuków: naturalnego - Tyberiusza Gemellusa, i przybranego -

${ }^{28}$ CIL 11.4170=Dessau, ILS 157 (Interamna Nahars). Szerzej na ten temat ostatnio zob. K. Balbuza, Aeternitas Augusti, op. cit., s. 65-66 i 179-180.

${ }^{29} \mathrm{~K}$. Cichorius, Römische Studien, historisches, epigraphisches, literargeschichtliches aus vier Jahrhunderten Roms, Leipzig - Berlin 1922, s. 180.

${ }^{30}$ CIL 9.4209=Dessau, ILS 163 (Amiternum). 
Kaliguli31. Ta oddolna inicjatywa dowodzi skali rozpowszechnienia się $\mathrm{w}$ tym czasie formuły i idei aeternitas $\mathrm{w}$ relacji z osobą cesarza i członkami rodziny cesarskiej.

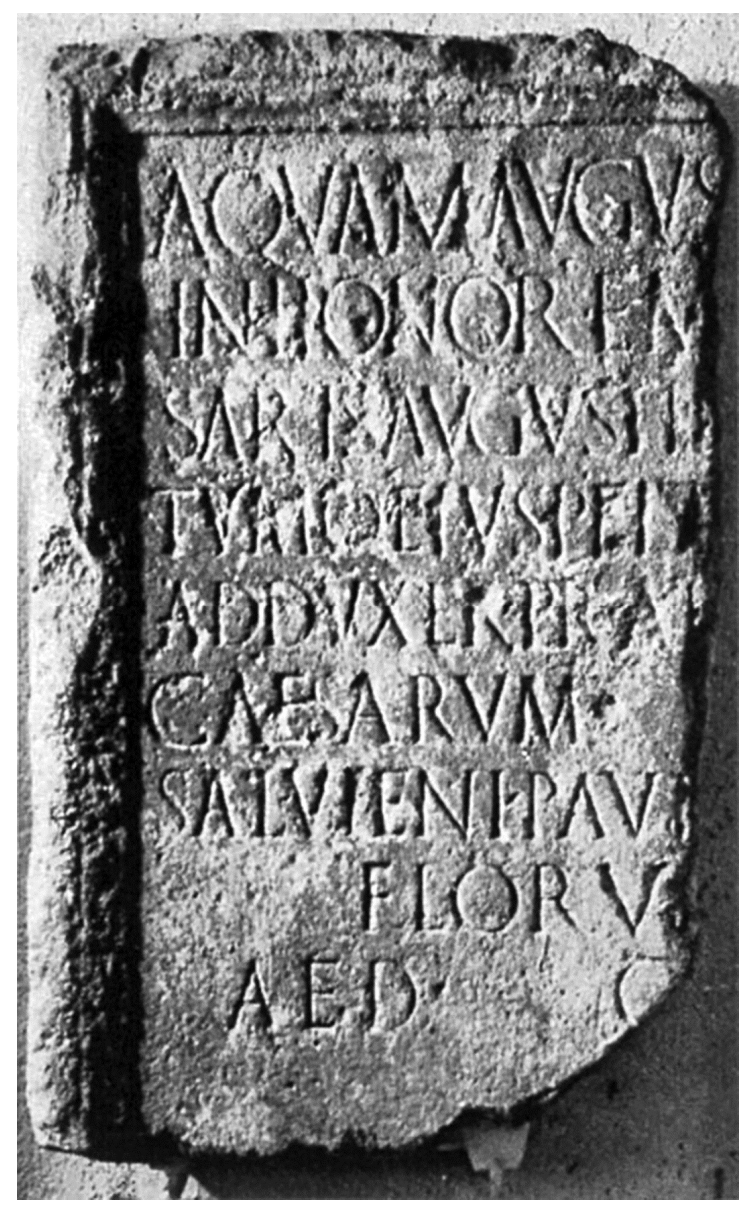

Il. 3. CIL 9.4209=Dessau, ILS 163 (Amiternum, Samnium, Włochy). Museo Nazionale d'Abruzzo, L'Aquila; http://cil.bbaw.de/test06/bilder/datenbank/PH0008576.jpg [dostęp: 15.08.2013 r.]

Warunkiem zapewniania aeternitas państwu przez cesarza była jego opatrzność, tudzież zdrowie i bezpieczeństwo. $Z$ tego względu pojawiają się w źródłowych wzmiankach na temat aeternitas dedykacje kierowane zarów-

31 Suet. Cal. 14. Więcej na ten temat zob. K. Balbuza, Aeternitas Augusti, op. cit., s. 66-67 i $143-144$. 
no ku cesarskiej salus, jak i providentia ${ }^{32}$. Przykładem jest tutaj - w odniesieniu do Tyberiusza - omawiana wyżej inskrypcja z Interamna Nahars czy w kontekście Nerona - zapis w aktach fratres Arvales (z ok. 66 r.) ${ }^{33}$. Co interesujące, okazją do obu wzmianek o gwarancji aeternitas dla państwa i specjalnej roli cesarza w jej zapewnianiu było stłumienie spisków na życie cesarzy. W pierwszym przypadku mowa o spisku prefekta gwardii pretoriańskiej, Sejana (L. Aelius Seianus), w drugim - o spisku Pizona (C. Calpurnius Piso). Oba wymienione przykłady aluzji do wieczności Rzymu (aeternitas Imperii) uwydatniają rolę cesarza $\mathrm{w}$ procesie zapewniania wiecznotrwałości państwa, a także znaczenie, jakie miały dla niej zdrowie i życie cesarza ${ }^{34}$.

Rola cesarza, zdolnego do zapewnienia wieczności państwa, była uwypuklana również w kontekście przeciwdziałania spekulacjom finansowym, manifestowania dbałości i troski cesarza o rolnictwo i estetykę krajobrazu Italii. Dokumentuje to dekret senatu („Senatus Consultum de aedificiis non diruendis" / "Senatus Consultum Hosidianum") ${ }^{35}$ uchwalony za Klaudiusza (z dnia 22 września 47 r.), za konsulatu Gnejusza Hosidiusza Gety oraz Lucjusza Wageliusza. To kolejny przykład przenikania się idei wieczności w odniesieniu do cesarza i państwa (w tym przypadku Italii). Zagrożeniem dla aeternitas - $\mathrm{w}$ tym przypadku Italii - mogły być niszczycielskie i szkodliwe praktyki, których dekret zakazywał. Cesarska troska o wieczność państwa (aeternitas Imperii) mogła się przejawiać także w organizacji igrzysk. Mowa tutaj o igrzyskach z 59 roku ${ }^{36}$, zorganizowanych z inicjatywy Nerona dla uwiecznienia cesarstwa („,pro aeternitate Imperii” ${ }^{\prime \prime}$ ).

$32 \mathrm{Na}$ temat providentia w kontekście aeternitas zob. M.P. Charlesworth, Providentia and Aeternitas, „Harvard Theological Review” 1936, nr 29(2), s. 107-132. Por. też: K. Balbuza, Aeternitas Augusti, op. cit., s. 179-182.

33 CIL 6.2044=6.32355. Fragm. I c, d 1-6.

34 Zob. K. Balbuza, Aeternitas Augusti, op. cit., s. 179-182.

35 CIL 10.1401=Dessau, ILS 6043=FIRA 1.45. E.J. Philips, The Roman Law on the Demolition of Buildings, „Latomus” 1973, nr 32, s. 86-95; Documents Illustrating the Principates of Gaius, Claudius and Nero, coll. by M.E. Smallwood, Cambridge 1967, s. 93-94, nr 365. W kontekście aeternitas por. ostatnio: K. Balbuza, Aeternitas Augusti, op. cit., s. 190-192, gdzie analizuję również inne przypadki wzmiankowania aeternitas w kontekście dbałości cesarza o stan państwa.

${ }^{36}$ Suet. Nero 11. Por. też: Suet. Ner. 12; Cass. Dio 61.17.2-18.2. Na temat aeternitas za Nerona zob. ostatnio: K. Balbuza, Aeternitas Augusti, op. cit., s. 68-70. Data igrzysk ma charakter hipotetyczny. Więcej na ten temat: ibidem, s. 68, przyp. 309.

37 Nazwa ta ma charakter niejednoznaczny, mogła bowiem oznaczać zarówno imperium cesarza, jak i teren obowiązywania jego władzy (F. Cumont, L'éternité des empereurs romains, „Revue d'Histoire et de Littérature Religieuses” 1896, nr 1, s. 437; W. Köhler, Personifikationen abstrakter Begriffe auf römischer Münzen, Diss. Königsberg 1910, s. 31; J. Beaujeu, La religion romaine a l'apogée de l'Empire. I. La politique religieuse des Antonins (96-192), Paris 1955, s. 146), a nawet, być może, wieczność samego cesarza (H.U. Instinsky, op. cit., s. 329). O dwuznaczności tej formuły zob. też: J. Beaujeu, op. cit., s. 146. 
Charakterystyczne dla okresu rządów dynastii julijsko-klaudyjskiej wzmianki o aeternitas $\mathrm{w}$ relacji $\mathrm{z}$ osobą cesarza oraz ze sprawowaną przez niego władzą uwypuklają przede wszystkim rolę princepsa - zarówno żyjącego, jak i zmarłego, a następnie ubóstwionego - w procesie zagwarantowania wieczności państwa. Aeternitas podkreślała również trwałość władzy cesarskiej, tudzież wiecznotrwałość terytorium, na którym tę władzę sprawowano. Zarówno w tym wczesnym okresie kształtowania się pryncypatu, jak również później, aeternitas przypisywana cesarzowi warunkowała aeternitas państwa. Obie idee - aeternitas Imperii i aeternitas Augusti - będą się przenikały na przestrzeni dziejów pryncypatu, kiedy to, z jednej strony, opiewano wiecznotrwałość państwa oraz bóstw za nią odpowiedzialnych, z drugiej - gwarantów tej wiecznotrwałości, czyli princepsów - najpierw żyjących i wypełniających swoje obowiązki państwowe, a po śmierci - ubóstwionych. Refleksje z czasów Augusta podkreślały aeternitas boskiej natury princepsa oraz jego sakralny związek z kultem Westy. Ten drugi aspekt ma szczególne znaczenie dla idei wiecznotrwałości państwa i roli, jaką miał w jej zapewnieniu odegrać cesarz. Decyzja Augusta o ideologicznym sprzężeniu kultu bogini Westy, ognia i innych elementów świadomości rzymskiej - z osobą władcy, czego widocznym znakiem było ustanowienie na Palatynie przybytków Westy i Apollona w 12 roku p.n.e., miała bowiem swoją symbolikę i konsekwencje. Dzięki szczególnej relacji z Westą, a także z innymi bogami, oraz dzięki rozwojowi różnych form oddawania czci boskiej cesarzowi, wyrażano przeświadczenie, że charyzmatyczna osobowość cesarza wynikała w dużej mierze właśnie z aeternitas. Ona bowiem stawała się na przestrzeni dziejów pryncypatu nieodłącznym atrybutem władcy i przypisaną mu cechą lub jakością. Przeświadczenie, że do zagwarantowania wieczności Rzymu potrzebny będzie wieczny cesarz, doprowadziło już za Tyberiusza do pojawienia się $\mathrm{w}$ mennictwie konsekracyjnym formuły aeternitas Augusta („wieczność cesarska”). Po przeanalizowaniu wszystkich zachowanych świadectw źródłowych dokumentujących aeternitas cesarza konsekrowanego trzeba jednak stwierdzić, że Rzymianie zachowywali daleko posunięty umiar w jej wychwalaniu. Spośród wszystkich cesarzy, którzy otrzymali od senatu tytuł divus (boski) oraz zapewniono im zewnętrzne formy kultu - świątynię i kapłanów - wychwalanie pośmiertnej aeternitas udokumentować można w zaledwie czterech przypadkach - Augusta, Wespazjana, Pertynaksa i Klaudiusza II Gockiego ${ }^{38}$. Aeternae były również dwie cesarzowe: Faustyna Starsza i Faustyna Młodsza ${ }^{39}$.

38 Divus Augustus: RPC 1.29; 219; 222, 224; RPC 1, Suppl. 2, 29. Por. RPC 1, 47-48; RPC 1, Suppl. 2, 47; RPC 1, 226. Divus Vespasianus: RIC 2.1, Tit. 380-381. Divus Pertinax: F. Gnecchi, 
Konteksty, w których eksponowano aeternitas Augusti za czasów dynastii julijsko-klaudyjskiej, były, najogólniej rzecz biorąc, związane z jednej strony z działalnością, obowiązkami i wyjątkowym statusem cesarza, z drugiej z jego bezpieczeństwem i zdrowiem. Sprawowana przez niego władza, wspierana i chroniona przez bogów, polegała na zapewnieniu bezpieczeństwa (incolumitas) na granicach i spokoju wewnętrznego (securitas), pielęgnacji zgody w państwie (concordia) i zapobieganiu sporom wewnętrznym (seditio), które mogły zniweczyć zgodę (concordia). Oprócz troski o pignora Imperii i państwo, cesarz miał obowiązek dbać o ogólną pomyślność kraju i obywateli. Był postrzegany jako gwarant wiecznotrwałości państwa, mąż opatrznościowy Rzymu. Cechująca go providentia, o której wspominają źródła epigraficzne $\mathrm{z}$ czasów Tyberiusza i Nerona ${ }^{40}$, pomagała $\mathrm{w}$ zapewnieniu państwu aeternitas. Jednym $\mathrm{z}$ ważniejszych aspektów kształtującej się idei aeternitas Augusti w ideologii władzy cesarskiej była dbałość o kontynuację linii dynastycznej, co przyczyniało się do „przedłużenia” trwania Rzymu. W drodze ideologicznych nawiązań do mitu Romulusa i założenia Rzymu wywoływano przeświadczenia o nowym założycielu (conditor), który w krytycznych chwilach istnienia państwa - wskrzesi je. Ideologia ponownego zakładania urbs była modna już za Augusta, co było przyczyną kojarzenia tego ostatniego z Romulusem.

Początki idei aeternitas ujmowanej $\mathrm{w}$ odniesieniu do osoby princepsa miały w opisywanym czasie głównie charakter oddolny. Są dzięki temu dobrym miernikiem ówczesnej recepcji społecznej osoby cesarza i sprawowanej przez niego władzy w kategoriach wieczności ${ }^{41}$. Kierunek rozwoju aeternitas cesarza stopniowo zmierzał do jej stopniowego indywidualizowania, silniejszego powiązania z osobą princepsa. Literalne poświadczenie idei aeternitas Augusti nastąpi dopiero za Flawiuszy. Najpierw było to jedynie umieszczone na monetach hasło "AETERNITAS POPVLI ROMANI", następnie samo słowo „AETERNITAS”. Dopiero za Tytusa i kolejnych cesarzy doszedł epitet „AUGUSTI"42. U schyłku II i na początku III wieku, kiedy

I medaglioni romani descritti ed illustrati da Francesco Gnecchi, Vol. 2, Milano 1912, nr 1, s. 72. Divus Claudius Gothicus: RIC 5.1, Claud. 270.

${ }^{39}$ Diva Faustina: RIC 3, Ant. Pius 344-355; 1100-1115; 1154-1168; 1182-1183; Gnecchi 2.1-2, s. 24. Diva Faustina Pia: RIC 3, M. Aur. 738-740; 1691-1699.

${ }^{40}$ CIL 11.4170=Dessau, ILS 157 (Interamna Nahars); CIL 6.2044=6.32355. Fragm. I c, d 1-6.

${ }^{41} \mathrm{M}$. Horster, Bauinschriften römischer Kaiser. Untersuchungen zu Inschriftenpraxis und Bautätigkeit in Städten des westlichen Imperium Romanum in der Zeit des Prinzipats, Stuttgart 2001, s. 104.

${ }^{42} \mathrm{Na}$ temat obecności idei aeternitas oraz analizy ikonografii aeternitas $\mathrm{w}$ mennictwie zob. K. Balbuza, La conception..., op. cit., s. 93-108; eadem, AVGVSTA IN AETERNITATE. Motyw wieczności w Rzymie Antoninów ze szczególnym uwzględnieniem Faustyny Starszej, w: Hortus Histo- 
cesarstwo przeżywało ciężki kryzys, idea aeternitas Augusti zyskała na znaczeniu. W czasach Sewerów obserwujemy zdecydowany awans idei wiecznotrwałości państwa/władzy (aeternitas Imperii), upamiętnianej w mennictwie za pomocą wizerunków przedstawicieli dynastii, co pokazuje, że do zapewnienia wieczności nie było już niezbędne pośrednictwo zmarłych, wiecznych divi. O wolnym tempie ewolucji idei wieczności cesarskiej świadczy fakt, że dopiero w IV wieku epitet aeternus stał się elementem tytulatury cesarza rzymskiego ${ }^{43}$.

\section{Wykaz skrótów bibliograficznych zastosowanych w artykule:}

CIL: Corpus Inscriptionum Latinarum, consilio et auctoritate Academiae Scientiarum Germanicae editum, Berolini 1862-. Później: Academiae Scientiarum Berolinensis et Brandenburgensis editum. Od 1930 r. w Verlag de Gruyter, Berlin.

Dessau, IL: Inscriptiones Latinae Selectae, ed. H. Dessau, Berlin 1892-1916.

FIRA: Fontes Iuris Romani Antejustiniani, pars prima: leges itervm ed. S. Riccobono et all., Florentiae 1941.

Gnecchi: F. Gnecchi, I medaglioni romani descritti ed illustrati da Francesco Gnecchi, Vol. 1-3, Milano 1912.

RIC: The Roman Imperial Coinage, Vol. 2.1: From AD 69-96. Vespasian to Domitian, ed. by I.A. Carradice et all., London 2007; Vol. 3: Antoninus Pius to Commodus, ed. by H. Mattingly, E.A. Sydenham, London 1930; Vol. 5.1: Valerian I to the Interregnum, ed. by H. Mattingly [et al.], London 1927.

RPC: Roman Provincial Coinage, Vol. 1. From the Death of Caesar to the Death of Vitellius (44 $B C-A D$ 69). Part 1: Introduction and Catalogue, ed. by A. Burnett [et al.], London 1992; Vol. 1, Suppl. 2, ed. by A. Burnett [et al.], London 2006.

\section{Aeternitas Augusti - Origins and Development Direction of the Emperor's Eternity Idea}

\section{Summary}

Although the first unambiguous original proofs of the aeternitas Augusti idea come from the Flavian dynasty, its origin lies in the period of the late Republic and

riae. Księga Pamiątkowa ku czci Profesora Józefa Wolskiego w setna rocznicę urodzin, red. E. Dąbrowa [et al.], Kraków 2010, s. 393-409; eadem, Personifikacja Aeternitas na monetach rzymskich propagujacych idee wieczności cesarza, „Studia Europaea Gnesnensia” 2013, nr 8, s. 7-27; eadem, Aeternitas Augusti, op. cit., passim.

${ }^{43}$ Szeroko nt. ewolucji idei aeternitas Augusti zob. K. Balbuza, Aeternitas Augusti, op. cit., passim. 
Principate. Aeternitas was a deified abstraction, which expressed the state the emperor could obtain as a result of deification. It was also an attribute of the emperor, the property of his divine nature. Analysis of the places and contexts of the occurrence of the eternity phenomenon with respect to the emperor in preserved sources suggests that the ideas of the state and the emperor's eternity were complementary and mutually conditioned. The emperor's aeternitas was declared to emphasize his religious and political role in the state, in the process of granting him everlastingness. It was discussed in the context of concerns about his health and safety, particularly in the context of neutralizing plots to assassinate him, and in the context of the implications to the policy of the throne. Despite the fact that proclaiming the emperor's aeternitas in the Julio-Claudian dynasty had no official character, the number and diversity of its original evidences prove the significant popularity of this idea in society.

Słowa kluczowe: aeternitas Augusti, wieczność cesarza, pignora Imperii, ideologia władzy, Westa

Keywords: aeternitas Augusti, eternity of the emperor, pignora Imperii, ideology of power, Vesta

DOI: $10.14746 /$ cbes.2016.15.17 